\title{
PERAN PRODUCT QUALITY, INFORMATION QUALITY DENGAN MEDIASI TRUST TERHADAP REPURCHASE INTENTION PADA MITRA UMKM GO-FOOD DI SURAKARTA
}

\author{
Septi Kurnia Prastiwi, Rabia, Renanda Bagus \\ IAIN SURAKARTA \\ Surakata \\ Septikurnia83@gmail.com, Rabia061295@gmail.com, Renan11bw.24@gmail.com
}

\begin{abstract}
Abstrak
Penelitian ini bertujuan untuk menganalisis beberapa faktor yang dapat meningkatkan repurchase Intention pada mitra UMKM go-food. Dua variabel yang diduga dapat mempengaruhi repurchase intention adalah product quality dan information quality dengan mediasi trust. Penelitian ini menggunakan metode survei dengan populasi user Go-jek yang pernah order go-food di Surakarta, dengan sampel sebanyak 100 responden, dengan pengambilan sampel purposive sampel, dan kuisioner dengan 19 indikator pertanyaan. Hasil uji validitas, reliabilitas, dan uji asumsi klasik mendukung untuk melanjutkan penelitian. Hasil uji path analisis mendapatkan hasil bahwa variabel product quality tidak berpengaruh signifikan terhadap trust dan Repurchase Intention, variabel information quality berpengaruh positif dan signifikan terhadap variabel trust dan dependen Repurchase Intention. Untuk menguji apakah variabel trust dapat menjadi variabel mediator antara information quality dengan repurchase intention, dibuktikan dengan hasil uji sobel test yang menemukan bahwa variabel trust signifikan sebagai variabel mediator.
\end{abstract}

Kata kunci: Kualitas Produk, Kualitas Informasi, Kepercayaan, Niat Pembelian Ulang

\begin{abstract}
This study aims to examine the factors that may affect repurchase intention for Go food product. Two variables suspected to affect the repurchase intention are product quality and information quality with trust as mediation. The design of this study is survery method with a population of go jek user in Solo, with sample size of 100 respondents, the sampling methods purposive sampling a questionnaire with 12 indicators questions. Test results validity, reliability and classic assumption test support for continuing research. Path analysis get the result that variable product quality not significantly affect trust and repurchase intention, but variable information quality can affect positively and significantly related to trust and the dependent variable repurchase intention. To examine variable trust can be mediator variable product quality to repurchase intention, evidence by sobel test and get the result that variable trust significantly as mediator variable.
\end{abstract}

Keywords: Product Quality, Information Quality, Trust, Repurchase Intention

\section{Pendahuluan}

Pada era digital saat ini, perkembangan teknologi informasi ternyata banyak memberikan timbal balik yang positif. Seperti banyaknya peluang bisnis baru yang tercipta khususnya pemanfaatan pada internet. Pola ekonomi masyarakat beralih menjadi konsumen yang lebih 
mengarah pada konsumsi e-commerce. Fenomena ini menunjukkan bahwa pelaku ekonomi digital sangat cepat memanfaatkan kemampuan teknologi dan merubah pola fikir masyarakat tentang jual beli (CNN, 2017). Salah satu perusahaan di Indonesia yang memanfaatkan E-commerce dan penggunaan praktisnya melalui smartphone adalah perusahaan Go-jek. Dalam perkembangannya, Go-jek terus melakukan inovasi dengan mengembangkan fitur yang ditawarkan, selain layanan transportasi Gojek juga berusaha memenuhi kebutuhan gaya hidup dan logistik di dalam satu aplikasi. Sehingga Go-jek mampu menjadi Market Place berbagai layanan seperti Go-Car, GoFood, Go-Mart, Go-Send, Go-Box, Go-Pulsa, Go-Massage, Go-Clean, Go-Glam, Go-Tix, Go-Auto, Go-Med, Go-Busway. Market place mulai menjadi primadona kalangan konsumen karena konsumen saat ini lebih tertarik membeli barang di layanan penyedia jual beli. Aktivitas masyarakatpun menjadi berubah dan terlihat praktis, karena tidak perlu jauh keluar kota, ketoko, antri di rumah makan, dan mengurangi biaya belanja di mall (CNN, 2017).

Salah satu layanan yang cukup populer di Go-jek yaitu layanan Go-Food. Layanan ini memudahkan konsumen yang mempunyai aplikasi Go-Jek untuk memilih dan memesan makanan dengan layanan delivery order dari Go-Ride. Kemudahan pembayaran juga mendorong konsumen untuk memesan order Go-Food. Konsumen merasa diuntungkan karena lebih efisien waktu dan tenaga juga biaya untuk menuju rumah makan yang diinginkan. Kehadiran Go-food ini tentu memudahkan konsumen dalam order kuliner, tetapi juga berdampak bagi para pelaku UMKM dibidang kuliner untuk dapat mengembangkan usahanya dengan bergabung menjadi mitra Go-Food. Produk Kulinernya akan muncul dalam aplikasi Go-food sehingga dapat lebih dikenal oleh masyarakat. Hal ini menjadi alternatif bagi mitra UMKM di bidang kuliner untuk mempromosikan produknya melalui aplikasi Go-Food.
Data internal Go-Jek mencatat ratarata transaksi UMKM meningkat 2,5 kali sejak bergabung dengan Go-Food. Go-jek mengungkapkan mayoritas mitra merchant Go-food adalah kategori pengusaha kecil dan menengah, $80 \%$ daripada bisnis go food adalah bisnis UMKM, total merchant Go Food saat ini ada 125.000 merchant (industri. bisnis.com,2018). Fitur layanan Go-Food menurut CEO Go-jek mampu meningkatkan omzet penjualan dan keluwesan para pelaku UMKM di sejumlah wilayah Indonesia, menurutnya mayoritas pengguna GoJek cenderung menyukai makanan lokal. Makarim menjelaskan, sebanyak 30 persen dari omzet UMKM itu datangnya dari GoFood (Tempo, 2018). Hasilnya Go-food benar-benar dibutuhkan oleh kalangan yang sudah paham akan pergerakan teknologi dan mulai berubah dari pemasaran konvensional menjadi pemasaran yang berbasis digital. Gofood dapat membantu penghematan biaya dan menjadikan jual beli lebih mudah dilakukan. Langkah ini berpotensi membuka pasar baru yang semula pasar tertutup menjadi lebih terbuka, karena mudahnya akses dan harga yang transparan dan menjadikan setiap penjual menjadi lebih cerdas dalam strategi pemasarannya (Tribunnews.com, 2017).

Melihat perkembangan Go-jek yang terus mengarah kepada peluasan inovasi dan memberikan peluang besar kepada setiap UMKM, maka penting untuk setiap mitra kuliner yang tergabung dalam Go-Food untuk mengetahui bagaimana selera dan kenyamanan konsumen dalam melakukan orderan di Go-Food, serta meningkatkan daya saing mitra Go-Food agar dapat bersaing dengan kompetitor. Pada Aplikasi Go-Food konsumen akan melihat tampilan produk yang dijual pada aplikasi tersebut, sehingga para mitra Go-Food bersaing dengan tampilan yang ada pada aplikasi tersebut untuk dapat menarik minat konsumen. Tantangan bagi mitra Go-Food untuk dapat menarik minat konsumen dengan membuat tampilan yang baik, information guality yang baik diharapkan dapat meningkatkan kepercayaan 
terhadap produk yang dijual oleh mitra GoFood dan selanjutnya akan terjadi repurchase intention pada produk mitra go-food tersebut. Hal ini sesuai dengan hasil penelitian Wang ,et.al (2009) yaitu adanya hubungan positif antara kualitas informasi dengan kepercayaan dan pembelian ulang secara online. Product quality juga harus diperhatikan juga oleh para mitra Go-Food, jika produk yang dijual baik kualitasnya diharapkan juga akan meningkatkan pembelian ulang ,menurut Palma (2016 ) yang mengatakan bahwa kualitas produk berpengaruh positif terhadap pembelian ulang secara online.

Menurut Kotler (2003) kualitas produk merupakan kemampuan produk menghasilkan sesuatu yang lebih dari ekspektasi pelanggan. Dalam persaingan era digital, kualitas produk menjadi hal yang seharusnya diperhatikan produsen (Saidani \& Arifin, 2012). Kualitas produk yang ditampilkan harus mempunyai nilai lebih dan dapat bersaing. Berawal dari kualitas produk yang baik, maka kepercayaan konsumen akan terbentuk dengan sendirinya, Sebab konsumen percaya bahwa kualitas yang diberikan sesuai dengan yang ditawarkan. Dalam hal ini diharapkan konsumen menumbuhkan rasa percaya terhadap produk setelah mengetahui kualitas produk, karena pembeli rekreasi cenderung mempertimbangkan kualitas, variasi produk jenis dan suasana toko yang menyenangkan sebagai faktor penting saat memilih produk (Alkilani, Ling, \& Abzakh, 2012; Chinomona \& Pooe, 2013)

Teori ini semakin diperkuat oleh hasil penelitian terdahulu (Palma, 2016) yang mengatakan bahwa kualitas produk berpengaruh positif terhadap pembelian ulang secara online. Hal yang sama juga diungkapkan oleh hasil penelitian Widjaja (2013) bahwa kualitas produk berpengaruh secara positif terhadap niat pembelian ulang sacara online. Selain itu penelitian chinomona juga mendukung bahwa kualitas produk berpengaruh positif terhadap kepercayaan (Chinomona \& Pooe, 2013). Dari teori dan hasil penelitian terdahulu diajukan hipotesis sebagai berikut.

H1: Kualitas Produk berpengaruh signifikan terhadap kepercayaan.

H3: Kualitas Produk berpengaruh signifikan terhadap niat pembelian ulang.

Selain product quality, information quality juga menjadi salah satu penyebab konsumen merasa percaya dengan semua tampilan dan layanan yang ada pada layanan Go-Food, dan kemungkinan besar menumbuhkan rasa loyal serta melakukan pembelian ulang pada makanan dan kios yang sama. Adapun yang dimaksud dengan kualitas informasi yaitu kualitas yang mengacu kepada jumlah, akurasi dan bentuk informasi tentang produk dan layanan yang ditawarkan dalam suatu situs (Sam \& Tahir, 2009), yang bertujuan untuk menarik perhatian calon pelanggan melalui produk atau layanan yang ditawarkan melalui sebuah situs atau website (Sam \& Tahir, 2009). Presentasi mengenai kejelasan produk atau konten tertentu akan menarik pelanggan untuk mengetahui lebih lanjut mengenai suatu produk, karena produk atau konten yang ditampilkan masih menjad iisu yang paling dipertimbangkan dalam melakukan pembelian online. Kualitas informasi menjadi bagian bangunan dari bisnis e-commerce. Kualitas ini menjelaskan sejauh mana individu dapat dengan mudah mendapatkan akses dan pemahaman informasi yang dibutuhkannya. Menurut Lin (2000), kriteria yang menjadikan kualitas informasi yang sering digunakan adalah kengkapan, tingkat akurasi, keterkaitan mata uang, dan kemudahan dalam akses. Produk dengan tingkatan kualitas yang baik akan membantu pengguna dalam berbelanja dan memilih pembelian yang terbaik (Alkilani et al., 2012).

Hal ini merupakan salah satu tindakan akan yang akan dilakukan oleh konsumen sebelum melakukan pembelian produk, seperti mencari kualitas informasi yang akurat, lengkap mudah diakses serta menimbulkan 
rasa yakin pada diri konsumen yang akan memunculkan rasa percaya dari konsumen untuk melakukan pembelian dengan pertimbangan tersebut (Wang et al., 2009). Teori ini semakin diperkuat lagi dengan hasil penelitian Wang yang menunjukan adanya hubungan positif antara kualitas informasi dengan kepercayaan dan pembelian ulang secara online. Selain itu, penelitian lainnya juga mendukung hubungan kualitas informasi dengan pembelian ulang secara online (Anggraeni, 2018, Sam \& Tahir, 2009).

Berdasarkan beberapa teori dan hasil penelitian terdahulu diajukan hipotesis sebagai berikut.

\section{H2: Kualitas Informasi berpengaruh positif terhadap kepercayaan}

H4: Kualitas Informasi berpengaruh positif terhadap niat pembelian ulang.

Hipotesis diatas semakin diperkuat dengan pernyataan bahwa kepercayaan merupakan dimensi hubungan bisnis untuk menentukan tingkat yang dirasakan masingmasing pihak yang dapat mengandalkan integritas dari janji yang ditawarkan oleh pihak lainnya (Sam \& Tahir, 2009). Menurut Fukuyama (1995), kepercayaan merupakan suatu harapan yang hadir pada perilaku yang bersifat jujur dan kooperatif (Warren et al, 2014). Menurut Luhmaan (2000), kepercayaan merupakan jalan keluar untuk resiko yang spesifik dan mampu memberikan pengaruh kepada keyakinan seseorang dalam hal pembelian (Vos et al, 2014). Kepercayaan menjadi factor pembeda dalam hal pengembangan e-commerce, karena arah bisnis sudah beralih ke era digital dimana kepercayaan menjadi kunci kesuksesan dalam bagian bisnis dan dapat menjadi penyebab konsumen melakukan pembelian ulang (Vos et al, 2014).

Hadirnya faktor kepercayaan akan mengurangi munculnya resiko dalam pembelanjaan. Menurut Greatorex dan Mitchell (1994), penyebab hadirnya resiko karena persepsi yang dirasakan dikarenakan pembeli merasa ketidakpastian terkait barang dan pengetahuan calon pembeli (Vos et al, 2014). Kepercayaan mampu menjadi salah satu pengaruh konsumen melakukan pembelian ulang produk. Menurut Ganguly et al (2009), persepsi konsumen saat ini terhadap toko online semakin besar dan akibatnya akan menimbulkan rutinitas dalam berbelanja online (Oghazi et al, 2018). Kepercayaan yang begitu tinggi dapat menghilangkan keraguan yang dimiliki pelanggan pada situs web yang mereka percaya, besar kemungkinan konsumen akan berniat belanja lagi pada web tersebut (Razak et al, 2014).

Kepercayaan merupakan kondisi awal yang harus ditanamkan terhadap konsumen online untuk mendorong konsumen agar berbelanja suatu produk atau layanan secara online (Sam \& Tahir, 2009). Hal ini juga diperkuat dengan beberapa penelitian sudah membuktikan bahwa kepercayaan online memiliki dampak yang signifikan terhadap niat membeli kembali. Menurut Li et al (2008), untuk kepercayaan online yang menjadi fokus utama pada kepercayaan paling tepat adalah peran teknologi (Razak et al, 2014). Berdasarkan teori tersebut terlihat bahwa kepercayaan memberikan peran penting dalam pembelian ulang konsumen, baik dari dari penilaian kualitas produk maupun kualitas informasi produk. Maka dari itu penelitian ini mengangkat kepercayaan sebagai variabel mediasi hubungan antara kualitas produk dan kualitas informasi terhadap niat pembelian ulang konsumen online. Semakin diperkuat dengan hasil penelitian Sullivan (2018) juga mengungkapkan bahwa kepercayaan online memberikan dampak yang signifikan terhadap niat pembelian ulang secara online.

Dari beberapa teori dan penelitian terdahulu maka diajukan hipotesis sebagai berikut. 
H5: Kepercayaan online berpengaruh positif terhadap pembelian ulang online.

H6: Kepercayaan dapat dijadikan mediasi antara hubungan kualitas produk, kualitas informasi dengan niat pembelian ulang secara online.

Berdasarkan hipotesis yang diajukan, makapenelitian ini akan membahas beberapa faktor-faktor yang diduga akan menyebabkan konsumen untuk melakukan pembelian ulang terhadap mitra kuliner pada layanan GoFood antara lain variabel product quality, information quality dan trust

Tujuan Penelitian adalah untuk mengetahui apakah product quality berpengaruh signifikan terhadap trust, $u$ ntuk mengetahui apakah information quality berpengaruh signifikan terhadap trust, untuk mengetahui apakah product quality berpengaruh signifikan terhadap repurchase intention, untuk mengetahui apakah information quality berpengaruh signifikan terhadap repurchase intention, untuk mengetahui apakah trust berpengaruh signifikan terhadap repurchase intention, dan untuk mengetahui apakah trust dapat memediasi hubungan antara product Quality dan information quality terhadap repurchase intention.

\section{Metode Penelitian}

Penelitian ini menggunakan pendekatan kuantitatif, dengan metode expost facto. Desain penelitian ini menggunakan desain descriptive dan regresi dengan variabel mediatoryaitu dengan path analysis. Pengujian data dengan menggunakan program SPSS. Penelitian ini adalah survey yang dilakukan pada konsumen yang pernah membeli produk makanan maupun minuman melalui aplikasi Go-Food di area Surakarta.

Populasi menurut Ferdinand (2014: 171) adalah gabungan dari seluruh elemen yang berbentuk peristiwa, hal atau orang yang memiliki karakteristik yang serupa yang menjadi pusat perhatian seorang peneliti karena itu dipandang sebagai sebuah semesta penelitian. Populasi dalam penelitian ini adalah konsumen yang pernah membeli makanan melalui aplikasi Go-Food yang ada di area surakarta. Sampel dalam penelitian ini diambil sebanyak 100 responden.

Sumber data yang digunakan dari data primer dan sekunder. Pengambilan sampel dalam penelitian ini dengan teknik purposive yaitu judgement sampling. Judgment sampling, sampel dipilih dengan menggunakan pertimbangan tertentu yang disesuaikan dengan tujuan penelitian atau masalah penelitian yang dikembangkan (Ferdinand, 2014: 179). Kriteria yang bisa menjadi sample penelitian adalah konsumen yang mempunyai aplikasi Go-jek pada Handphone, serta sudah pernah membeli makanan maupun minuman melalui aplikasi Go-Food. Skala yang digunakan dalam penelitian ini adalah skala interval dengan rentang skala 1 sampai 10 mulai dari sangat tidak setuju hingga sangat setuju.

\section{Teknik Analisis Data}

a. Uji Instrumen Data cukup reliabel, nilai Cronbach's Alpha antara $0,61 \quad-\quad 0,80$ dikategorikan reliabel, dan nilai Cronbach's Alpha antara 0,81 - 1,00 dikatakan sangat reliabel.

b. Uji Asumsi Klasik

Dalam penelitian ini, uji asumsi klasik yang digunakan adalah uji normalitas, uji multikolonieritas, dan uji heteroskesdatisitas. Uji multikolinieritas bertujuan untuk menguji apakah model regresi ditemukan adanya korelasi antar variabel bebas (independen) (Ghozali;2016:103). Uji Heterokesdastisitas bertujuan menguji apakah dalam model regresi terjadi ketidaksamaan variance dari residual satu pengamatan ke pengamatan lain (Ghozali, 2016: 134).

c. Analisis Regresi Berganda Regresi ganda adalah suatu perluasan 
dari teknik regresi apabila terdapat lebih dari satu variabel bebas untuk mengadakan prediksi terhadap variabel terikat (Arikunto, 2006: 295). Adapun bentuk persamaanya sebagai berikut :

$\mathbf{Z}=\boldsymbol{\alpha}+\mathbf{b}_{1} \mathbf{X}_{1}+\mathbf{b}_{2} \mathbf{X}_{2}+\mathbf{e}$

$\mathbf{Y}=\boldsymbol{\alpha}+\mathrm{b}_{1} \mathbf{X}_{1}+\mathrm{b}_{2} \mathbf{X}_{2}+\mathrm{b}_{3} \mathrm{Z}+\mathrm{e}$

d. Uji Ketepatan Model

1) Uji Ketetapan Model, Koefisien Determinasi $\left(\mathrm{R}^{2}\right)$

Nilai koefisien determinasi pada intinya mengukur seberapa jauh kemampuan model dalam menerangkan variasi variabel dependen. Nilai koefisien determinasi adalah antara nol dan satu . Nilai $R^{2}$ yang kecil berarti kemampuan variabelvariabel independen dalam menjelaskan variabel-variabell dependen amat terbatas. Nilai yang mendekati satu berarti variabel-variabel independen memberikan hampir semua informasi yang dibutuhkan untuk memprediksi variasi variabel dependen (Ghozali, 2016: 97)

2) Uji F

Uji statistik $F$ pada dasarnya menunjukkan apakah semua variabel independen atau bebas yang dimaksudkan adlam model mempunyai pengaruh secara bersama-sama terhadap variabel dependen/terikat (Ghozali, 2016: 97)

3) Uji t

Uji statistik $t$ menunjukkan seberapa jauh pengaruh satu variable independen secara individual dalam menerangkan variable (Ghozali, 2016: 98). Untuk mengetahui apakah suatu variable secara parsial berpengaruh nyata atau tidak menggunakan uji statistik t. Dengan menggunakan angka probabilitas signifikansi, maka criteria pengambilan keputusan penelitian adalah sebagai berikut :

a) Apabila probabilitas signifikansi $>0,05$, maka Ho diterima dan Ha ditolak artinya variabelenvironemental value, environmental senitivity dan behavioral intention tidak berpengaruh terhadap variabel sustainable consumer behavior.

b) Apabila probabilitas signifikansi $<0,05$, maka Ho ditolak dan $\mathrm{Ha}$ diterima artinya variabel environemental value,environmental senitivity dan behavioral intention berpengaruh terhadap variabel sustainable consumer behavior (untuk tingkat signifikansi $=5 \%$ ).

c) Membandingkan nilai $\mathrm{T}$ hitung dengan $\mathrm{T}$ tabel

Apabila T tabel $>\mathrm{T}$ hitung, maka Ho diterima dan $\mathrm{Ha}$ ditolak.

Apabila $\mathrm{T}$ tabel $<\mathrm{T}$ hitung, maka Ho ditolak dan $\mathrm{Ha}$ diterima.

\section{e. Uji Sobel Test}

Sobel test digunakan untuk menguji apakahpengaruhvariableintervening yang dihasilkan pada analisis jalur signifikan atau tidak. Sobel test menghendaki asumsi jumlah sampel besar dan nilai koefisien mediasi berdistribusi normal (Ghozali, 2016: 255).Uji sobel merupakan uji untuk mengetahui apakah hubungan yang 
melalui sebuah variabel mediasi secara signifikan mampu sebagai mediator dalam hubungan tersebut. Uji sobel ini dilakukan dengan cara menguji kekuatan pengaruh tidak langsung variabel dependen (X) terhadap variabel independen (Y) melalui variabel intervening $(Z)$.

Pengaruh tidak langsung $\mathrm{X}$ keY melalui $Z$ dihitung dengan cara mengalikan jalur $X \rightarrow Z$ (a) dengan jalur $Z \rightarrow Y(b)$ atau ab. Jadi koefisien $a b=(c-c ')$, dimana $c$ adalah pengaruh $\mathrm{X}$ terhadap $\mathrm{Y}$ tanpa mengontrol $\mathrm{Z}$, sedangkan c' adalah koefisien pengaruh $X$ terhadap Y setelah mengontrol Z. Standar error koefisiena dan $b$ ditulis dengan Sadan $\mathrm{Sb}$, besarnya standar error tidak langsung (indirect effect) Sab dihitung dengan rumus berikut ini :

$$
S a b=\sqrt{b^{2} S a^{2}+a^{2} S b^{2}+S a^{2} S b^{2}}
$$

Untuk menguji signifikan si pengaruh tidak langsung, maka kita perlu menghitung nilai t dari koefisien ab dengan rumus sebagai berikut:

$\mathrm{t}=\frac{a b}{S a b}$

Nilai $t_{\text {hitung }}$ ini dibandingkan dengan nilai $t_{\text {tabel }}$ dan jika nilai $t_{\text {hitung }}$ lebih besar dari nilai $\mathrm{t}{ }_{\text {table }}$ maka dapat disimpulkan bahwa terjadi pengaruh mediasi

\section{Hasil dan Pembahasan}

\section{Uji Validitas Dan Reliabilitas}

Uji Validitas digunakan untuk mengukur valid atau tidaknya suatu kuisioner, suatu kuisioner dikatakan valid jika pertanyaan pada kuisioner mampu mengungkapkan sesuatu yang akan diukur oleh kuisioner tersebut (Ghozali; 2016:52). Validitas diuji dengan Confirmatory Factor Analysis (CFA). Alat uji lain yang yang digunakan mengukur tingkat interkorelai antar variabel dan dapat tidaknya dilakukan analisis faktor adalah Kaiser-Meyer-Olkin Measure of Sampling Adequacy (KMO MSA).
Nilai KMO bervariasi dari 0 sampai dengan 1. Nilai yang dikehendaki harus $>0.50$ untuk dapat dilakukan analisis faktor. Nilai $\mathrm{KMO}=$ 0,873 dan signifikan pada 0.000 , maka dapat disimpulkan bahwa uji analisis faktor dapat dilanjutkan.

Hasil rotasi faktor dengan metode varimax menunjukkan bahwa indikator product quality, information quality, trust dan repurchase intention semua memiliki factor loading diatas 0,5 dan mengelompok menjadi satu pada faktor masing-masing. Jadi dapat disimpulkan bahwa konstruk product quality memiliki unidimensionalitas begitu juga dengan konstruk information quality, trust dan repurchae intention atau dengan kata lain semua indikator valid.

Reliabilitas adalah alat untuk mengukur kuisioner merupakan indikator dari variabel. SPSS memberikan fasilitas untuk mengukur reliabilitas dengan uji statistik Cronbach Alpha $(\alpha)$. Menurut Nunnally dalam (Ghozali; 2016:48) suatu konstruk atau variabel dikatakan reliabel jika memberikan nilai Cronbach Alpha $>0.70$. Setelah semua indikator diuji, semua indikator memiliki nilai Cronbach Alpha $>0.70$, sehingga semua indikator pertanyaan sudah reliabel.

\section{Uji Asumsi Klasik}

Uji multikolinieritas bertujuan untuk menguji apakah model regresi ditemukan adanya korelasi antar variabel bebas (independen) (Ghozali;2016:103). Nilai Tolerance semua kurang dari 0.10 yang berarti tidak ada korelasi antar variabel independen. Hasil Nilai Variance Inflation Factor (VIF) semua variabel independen nilai VIF tidak lebih dari 10. Sehingga tidak terjadi multikolinieritas antar variabel independen dalam model regresi.

Uji Heterokesdastisitas bertujuan menguji apakah dalam model regresi terjadi ketidaksamaan variance dari residual satu pengamatan ke pengamatan lain (Ghozali, 2016: 134). Grafik scaterplots terlihat bahwa titik-titik menyebar secara acak serta tersebar baik di atas maupun di bawah angka 0 pada 
sumbu y. Hal ini dapat disimpulkan bahwa tidak terjadi heterokesdatisitas pada model regresi.

Uji normalitas bertujuan untuk menguji apakah dalam model regresi, variabel pengganggu atau residual memiliki distribusi normal (Ghozali; 2016:154). Uji statistik yang dapat digunakan untuk menguji normalitas residual adalah uji statistik non-parametrik Kolmogorov Smirnov (K-S). Uji K-S dilakukan dengan membuat hipotesis:

H0 : Data residual berdistribusi normal

HA: Data residual berdistribusi tidak normal

Besarnya nilai test statistik Kolmogorov Smirnov adalah 1.323 dan signifikan pada 0.061 diatas $\alpha=0.05$ hal ini berarti H0 diterima yang berarti data residual berdistribusi normal.

\section{Uji ketepatan model}

Koefisien determinasi $\left(\mathrm{R}^{2}\right)$ pada intinya mengukur seberapa jauh kemampuan model dalam menerangkan variasi variabel dependen (Ghozali , 2016:95).

\section{Koefisien Determinasi Persamaan 1}

Pada tabel, nilai Adjusted $\mathrm{R}$ Square sebesar 0,461 yang berarti bahwa $46 \%$ variabel product quality dan information quality mempengaruhi trust, dan 54\% dipengaruhi variabel lain diluar model penelitian ini.

\section{Koefisien Determinasi Persamaan 2}

Nilai Adjusted R Square sebesar 0,514 yang berarti bahwa $51 \%$ variabel trust, product quality dan information quality mempengaruhi repurchase intention, dan 49\% dipengaruhi variabel lain diluar model penelitian ini.

\section{Uji F}

a. Hasil Uji Anova Persamaan 1

Berdasrkan tabel hasil uji ANOVA atau $\mathrm{F}$ Test didapat bahwa $\mathrm{F}$ hitung sebesar 43,316 dengan probabilitas 0.000 , karena probabilitas jauh lebih kecil dari 0.05, maka model dapat digunakan untuk memprediksi trust.

b. Hasil Uji Anova Persamaan 2

Hasil uji ANOVA atau F Test didapat bahwa F hitung sebesar 35,860 dengan probabilitas 0.000 , karena probabilitas jauh lebih kecil dari 0.05, maka model dapat digunakan untuk memprediksi repurchase intention.

Pengujian hipotesis bertujuan untuk menentukan sebuah Ho yang akan diterima atau ditolak, hal ini sebagai dasar untuk menarik kesimpulan dalam penelitian. Secara statistik dapat diukur dari nilai koefisien determinasi, nilai statistik $\mathrm{F}$ dan nilai statistik t. Perhitungan statistik disebut signifikan secara statistik apabila nilai uji statistiknya berada dalam daerah kritis (daerah dimana Ho ditolak). Sebaliknya disebut tidak signifikan bila nilai uji statistiknya berada didalam daerah dimana $\mathrm{Ho}$ diterima.

\section{Hasil Uji Regresi Liner Berganda Persamaan 1}

Nilai $\mathrm{T}$ hitung variabel product quality sebesar 1.303 dan nilai $\mathrm{T}$ tabel untuk $\mathrm{N}=100$ dengan tingkat kesalahan 5\% adalah 1,98. Angka tersebut menunjukkan $\mathrm{T}$ hitung < Ttabel dan nilai Sig 0.196 lebih besar dari 0,05 . Ho diterima pada tingkat kepercayaan $95 \%$, artinya bahwa tidak terdapat pengaruh yang signifikan antara product quality terhadap trust. Hasil penelitian ini bertolak belakang dengan hasil penelitian (Chinomona \& Pooe, 2013). Berdasarkan tabel diatas dapat diketahui bahwa nilai $\mathrm{T}$ hitung variabel information quality sebesar 6.149 dan nilai $\mathrm{T}$ tabel untuk $\mathrm{N}=100$ dengan tingkat kesalahan $5 \%$ adalah 1,98. Angka tersebut menunjukkan Thitung $>$ Ttabel dan nilai Sig 0.000 lebih kecil dari 0,05 . Ho ditolak pada tingkat kepercayaan 95\%, artinya bahwa terdapat pengaruh yang signifikan antara information quality terhadap repurchase intention hasil penelitian ini selaras dengan hasil penelitian 
dari (Wang et al., 2009). Berdasarkan hasil uji hipotesis 1 pada penelitian ini didapatkan hasil product quality tidak berpengaruh signifikan terhadap trust. Sedangkan hasil uji hipotesis 2 menunjukkan hasil bahwa information quality berpengaruh signifikan terhadap trust.

\section{Hasil Uji Regresi Liner Berganda Persamaan 2}

Nilai $\mathrm{T}$ hitung variabel product quality sebesar -.063 dan nilai $\mathrm{T}$ tabel untuk $\mathrm{N}=100$ dengan tingkat kesalahan 5\% adalah 1,98. Angka tersebut menunjukkan $\mathrm{T}$ hitung < Ttabel dan nilai Sig 0.499 lebih besar dari 0,05 . Ho diterima pada tingkat kepercayaan $95 \%$, artinya bahwa tidak terdapat pengaruh yang signifikan antara product quality terhadap repurchase intention. Hasil penelitian ini bertolak belakang dengan hasil penelitian Widjaja (2013) yaitu product quality berpengaruh signifikan terhadap repurchase intention. Berdasarkan tabel diatas dapat diketahui bahwa nilai $T$ hitung variabel information quality sebesar 2.829 dan nilai $\mathrm{T}$ tabel untuk $\mathrm{N}=100$ dengan tingkat kesalahan $5 \%$ adalah 1,98. Angka tersebut menunjukkan Thitung $>$ Ttabel dan nilai Sig 0.006 lebih kecil dari 0,05 . Ho ditolak pada tingkat kepercayaan $95 \%$, artinya bahwa terdapat pengaruh yang signifikan antara information quality terhadap repurchase intention hasil penelitian ini selaras dengan hasil penelitian dari. (Wang et al., 2009).

Nilai $\mathrm{T}$ hitung variabel trust sebesar 5.398 dan nilai $\mathrm{T}$ tabel untuk $\mathrm{N}=100$ dengan tingkat kesalahan 5\% adalah 1,98. Angka tersebut menunjukkan Thitung $>$ Ttabel dan nilai Sig 0.000 lebih kecil dari 0,05. Ho ditolak pada tingkat kepercayaan $95 \%$, artinya bahwa terdapat pengaruh yang signifikan antara trust terhadap repurchase intention hasil penelitian ini selaras dengan hasil penelitian dari Sullivan (2018). Berdasarkan hasil uji hipotesis 3 pada penelitian ini didapatkan hasil product quality tidak berpengaruh signifikan terhadap repurchase intention. Sedangkan hasil uji hipotesis 4 menunjukkan hasil bahwa information quality berpengaruh signifikan terhadap repurchase intention. Hasil penelitian membuktikan bahwa H5 trust dapat berpengaruh signifikan terhadap repurchase intention.

Berdasarkan hasil penelitian diatas yang menunjukkan bahwa information quality berpengaruh signifikan terhadap trust dan repurchase intention, maka para mitra kuliner Go-Food diharapkan dapat meningktkan kualitas informasi yang dicantumkan pada aplikasi Go-Jek. Gambar maupu foto yang ditampilkan pada aplikasi Go-Jek dibuat semenarik mungkin, memberikan informasi produk dengan jelas dan detail, memberikan keterangan spesifikasi dan varians produk secara detail, memberikan informasi yang mudah dipahami oleh konsumen. Selanjutnya dengan informasi yang baik dan tampilan yang menarik akan membuat konsumen percaya pada produk yang dijual oleh mitra kuliner Go-Food, konsumen juga akan menilai bahwa kinerja mitra yang menjual kuliner tersebut baik. Selanjutnya jika konsumen sudah percaya diharapkan akan terjadi pembelian ulang pada mitra kuliner tersebut.

Untuk menguji Hipotesis 6 apakah variabel trust signifikan memediasi hubungan antara trust terhadap repurchase intention, maka diuji dengan sobel test. Hasil output SPSS memberikan nilai standardized beta product quality sebesar -.063 dan signifikansi pada 0.449 yang berarti product quality tidak signifikan mempengaruhi trust. Nilai koefisien unstandardized beta 0.302 merupakan nilai path atau jalur p2. Nilai unstandardized beta Informtation quality 0,246 merupakan nilai jalur path $\mathrm{p} 1$ dan nilai unstandardized beta Trust ke Repurchase intention 0.830 merupakan nilai jalur path p3. 


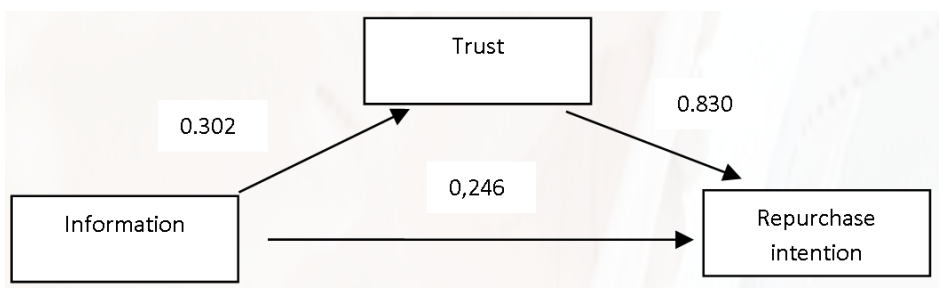

Gambar 1. Model Hasil Penelitian

Hasil analisis jalur menunjukaan bahwa Information quality dapat berpengaruh langsung ke repurchase intention sebesar 0,246, tetapi dapat berpengaruh tidak langsung terhadap repurchase intention yaitu dengan mediasi trust. Besarnya pengaruh tidak langsung harus dihitung dengan mengalikan koefisien tidak langsungnya yaitu; $0.302 \times 0.830=0.25$. Pengaruh mediasi yang ditunjukkan oleh perkalian koefisien p2 dan p3 sebesar 0.25 signifikan atau tidaknya diuji dengan sobel test, sebagai berikut:

$$
\begin{aligned}
& \mathrm{Sp} 2 \mathrm{p} 3=\sqrt{\mathrm{p}} 3^{2} \mathrm{Sp} 2^{2}+\mathrm{p}^{2} \mathrm{Sp} 3^{2}+\mathrm{Sp} 2^{2} \mathrm{Sp} 3^{2} \\
& \mathrm{Sp} 2 \mathrm{p} 3=\sqrt{ }(0.830)^{2}(0.049)^{2}+(0.302)^{2}(0.154)^{2}+ \\
& (0.049)^{2}(0.154)^{2}=0.15 \\
& \mathrm{t}=\underline{\mathrm{pp} 2 \mathrm{p} 3}=\underline{0.25}=1,667 \\
& 0.15
\end{aligned}
$$

Nilai t hitung $=1,667$ lebih besar dari $\mathrm{t}$ tabel dengan tingkat signifikansi 0.05 yaitu sebesar 1.66, sehingga dapat disimpulkan bahwa koefisien mediasi 0.25 signifikan, yang berarti ada pengaruh mediasi.

Berdasarkan hasil penelitian diatas, pentingnya para mitra UMKM Go-Food untuk dapat meningkatkan kepercayaan konsumen, yaitu dengan memberikan kulitas informasi yang jelas, baik dan menarik. Jika konsumen percaya terhadap informasi yang tertera pada tampilan di aplikasi Go-Jek, kemungkinan konsumen untuk melakukan pembelian ulang lebih tinggi.

\section{Penutup}

Kesimpulan dalam penelitian ini menunjukkan bahwa variabel product quality tidak berpengaruh siginifikan terhadap trust dan repurchase intention. Hasil uji hipotesis menunjukkan bahwa information quality berpengaruh positif dan signifikan terhadap trust dan repurchase intention. Hasil uji sobel test menunjukkan bahwa trust dapat memediasi hubungan antara information quality terhadap repurchase intention.

Para UMKM yang menjadi mitra GoFood dapat meningkatkan daya saing dengan meningkatkan kualitas informasi yang dicantumkan pada aplikasi Go-Jek, antara lain dengan gambar tampilan yang menarik, informasi mengenai spesifikasi, serta varians produk dibuat sedetail mungkin dan dapat dipahami konsumen. Selain itu mitra Go-food juga senantiasa meningkatkan kepercayaan konsumen sehingga dapat meningkatkan pembelian ulang. Pada penelitian selanjutnya diharapkan dapat mengembangkan faktorfaktor lain yang dapat meningkatkan repurchase intention pada Go-food.

\section{Daftar Pustaka}

Alkilani, K., Ling, K. C., \& Abzakh, A. A. (2012). The impact of experiential marketing and customer satisfaction on customer commitment in the world of social networks. Asian Social Science, 9(1), 262-270. https://doi.org/10.5539/ass.v9n1p262

Anuraga, W. (2015). Pengaruh Produk, Harga, Promosi, dan Merk Terhadap Keputusan Pembelian Ulang, 4.

Ariffin, S., Mohd, J., Putit, L., Izwan, M., \& Shah, A. (2016). Factors Influencing Perceived 
Quality and Repurchase Intention Towards Green Products. Procedia Economics and Finance, 37(16), 391-396. https://doi.org/10.1016/S2212-5671(16)30142-3

Chinomona, R., \& Pooe, D. (2013). The Impact of Product Quality on Perceived Value, Trust and Students ' Intention to Purchase Electronic Gadgets, 4(14), 463-472. https://doi. org/10.5901/mjss.2013.v4n14p463

Ghozali, Imam.2016. Aplikasi Analisis Multivariate dengan Program SPSS Edisi 8 . Badan penerbit UNDIP.

Ferdinand, Augusty. 2014. Metode Penelitian Manajemen Edisi 5. Badan penerbit UNDIP.

Oghazi, P., Karlsson, S., Hellström, D., \& Hjort, K. (2018). Journal of Retailing and Consumer Services Online purchase return policy leniency and purchase decision : Mediating role of consumer trust. Journal of Retailing and Consumer Services, 41(December 2017), 190-200. https://doi.org/10.1016/j.jretconser.2017.12.007

Palma, M. A. (2016). Pengaruh Kualitas Produk, Kemudahan, Dan Harga Terhadap Niat Beli Ulang Dengan Kepuasan Sebagai Variabel Intervening ( Studi Pada Pelanggan Produk Fashion Melalui Toko online di Surabaya ).

Razak, N. S. A., Marimuthu, M., Omar, A., \& Mamat, M. (2014). Trust and Repurchase Intention on Online Tourism Services among Malaysian Consumers. Procedia - Social and Behavioral Sciences, 130, 577-582. https://doi.org/10.1016/j.sbspro.2014.04.067

Saidani, B., \& Arifin, S. (2012). Pengaruh kualitas produk dan kualitas layanan terhadap kepuasan konsumen dan minat beli pada ranch market, 3(1), 1-22.

Sam, M. F. M., \& Tahir, M. N. H. (2009). Website Quality and Consumer Online Purchase Intention of Air Ticket. International Journal of Basic \& Applied Sciences, 9(10), 4-9.

Vos, A., Marinagi, C., Trivellas, P., \& Eberhagen, N. (2014). Risk Reduction Strategies in Online Shopping : E-trust perspective. Procedia - Social and Behavioral Sciences, 147, 418-423. https://doi.org/10.1016/j.sbspro.2014.07.122

Wang, M. C., Shih, E., Wang, T., Cheng, J. M., Wang, M. C., Wang, E. S., Chen, A. F. (2009). Information quality, online community and trust: A study of antecedents to shoppers $\hat{a} €^{\mathrm{TM}}$ website loyalty a study of antecedents to shoppers ' website loyalty, (January). https://doi.org/10.1504/IJEMR.2009.021806

Warren, A. M., Sulaiman, A., \& Jaafar, N. I. (2014). Social media effects on fostering online civic engagement and building citizen trust and trust in institutions. Government Information Quarterly. https://doi.org/10.1016/j.giq.2013.11.007

Www.cnn.com

www.industri.bisnis.com

www.tribunews.com

www.bisnis.tempo.co 